\title{
九州各地のウリ科作物から採集したワタアブラムシの キュウリにおける増殖能力
}

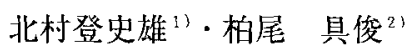 \\ (1) 野菜茶業研究所・21 九州沖縄農業研究センター)
}

\begin{abstract}
Reproductive ability of cotton aphid, Aphis gossipii, populations collected from cucurbitaceous vegetables in the Kyushu region. Toshio Kitamura ${ }^{13}$ and Tomotoshi Kashio ") (" National Institute of Vegetable and Tea Science, Anou, Mie 514-2392. Japan. ") National Agricultural Research Center for Kyushu Okinawa Region, Kurume, Fukuoka 839-8503. Japan)
\end{abstract}

Key words : Aphis gossipii, cotton aphids, population growth, cucumber

緒文言

ワタアブラムシ Aphis gossipii Glover は多くの作物を 加害する重要害虫であり，特にウリ科野菜で大きな問題 となっている。本種は吸汁による葉の萎縮や生育阻害だ けでなく，排泄物によるすす病の発生やCMVなどの ウィルス病を媒介するなどの多くの被害をもたらす。特 に施設栽培は露地栽培と比較してワタアブラムシの增殖 にとって非常に好適な条件であり，急激に增殖する(松 崎1972)。一方，ワタアブラムシには寄生性を異にする バイオタイプが存在することが知られて扔り，殺虫郕抵 抗性や增殖能力はバイオタイプにより異なる（細田ら。 1993）。また，寄生性の違いによるバイオタイプだけで なく，地域間に㧍いても殺虫剂抵抗性の変異が認められ ている（浜ら、1995）。このため地域個体群の間でも増 殖能力が異なることが予想される。天敵昆虫などを効率 的に利用するためにはワタアブラムシの増殖能力を詳細 に明らかにする必要があるが，これらの個体群間に打け る增殖能力に関する知見は少ない。そこで九州各地に扔 いてウリ科作物に寄生するワタアブラムシを採集し， キュウリを寄主とした場合の增殖能力を調查したので報 告する。

本文に先立ち供試したワタアブラムシを採集していた だいた大分県農業技術センター植物防疫部塩崎尚美氏， 宮崎県総合農業試験埸環境部黒木修一氏, 日本植物防疫 協会宫崎農場井園佳文氏に謝意を表する。
材料及び方法

\section{1．供試昆虫及び植物}

九州各地の現地围場で栽培されているウリ科作物から ワタアブラムシの無翅胎生雌虫を採集した(第 1 表)。

第 1 表 ウリ科作物から採集したワタアブラムシの 採集地と採集日

\begin{tabular}{clcl}
\hline 個体群 & \multicolumn{1}{c}{ 採集地 } & $\begin{array}{c}\text { 採集月日 } \\
(2000 \text { 年 })\end{array}$ & 寄主植物 \\
\hline $\mathrm{FC}-1$ & 福㘣県久留米市 & 6.15 & 施設キュウリ \\
$\mathrm{OC}-1$ & 大分県宇佐市 & 11.13 & 施設キュウリ \\
$\mathrm{NC}-1$ & 長崎県諌早市 & 11.20 & 施設キュウリ \\
$\mathrm{MC}-1$ & 宮崎県佐上原町 & 11.13 & 施設キュウリ \\
$\mathrm{MP}-1$ & 宮崎県川南町 & 11.20 & 露地カボチャ \\
\hline
\end{tabular}

それぞれの個体群から無翅胎生雌虫 1 個体を取り出し， これを親としてクローン個体群を育成した。アブラムシ 類のクローン別飼育法（村井，1991）によりソラマメの 芽だしを慨に実験室内で累代飼育した。これらのクロー ンをキュウリ葉上で2 世代鉰育したものを試験に供した。 実験に用いたキュウリ（品種：シャープ1）は, 径10 $\mathrm{cm}$ の黑色プラスティック製のポットに市販の育苗土 (@健苗）を入れ、栽培した。これらのキュウリには液 肥(@OKF1，1000倍液）を 1 週間ごとに施用した。

\section{2. 個体群パラメーターの調查}

径 $3 \mathrm{~cm}$ のプラスディック製ペトリ血の底に湿らせた 脱脂綿を敷き，その上にキュウリの葉を $2 \mathrm{~cm}$ 四方の葉 
片としたものを置き，切りロにティッシュペーパーを被 せた。出生後 24 時間以内のワタアブラムシを 1 頭ずつ キュウリの葉片上に置き，毎日定時刻に発育状況を調査 した。また供試した個体が成虫になったものについては 1日あたりの産子数を死亡するまで調查した。調査は $25^{\circ} \mathrm{C}$ ．16L 8 Dで行った。 4 〜 5 日ごとに新鮮な葉に交 換するとともに, ペトリ而中の脱脂綿が乾かないように 適宜給水した。

得られたデー夕を基に産下後の生存率（lx と 1 雌・ 1 日当たりの産子数 $(m x)$ 加純增殖率 (Ro) を(1)式 により，日あたり内的自然増加率 $(r)$ は(2)式の右辺が 1になるように左辺の $\Gamma$ にいるいるな値を与えて算出 した。このようにして計算した Ro, $r$ を(3)式に代入して 平均世代時間 $(\mathrm{T})$ を求めた。

$$
\begin{aligned}
& \text { Ro }=\sum_{x=0}^{\infty} l \mathrm{x} \cdot m x \\
& \sum_{x=0}^{\infty} e^{-r x} \cdot l \mathrm{x} \cdot m x=1 \\
& T=\frac{\ln R o}{r}
\end{aligned}
$$

統計検定は Kruskal-Wallis 検定と多重比輁のために Dunnの多重比較検定により産子前期間の比較を行った。

\section{結果及び考察}

九州各地のウリ科作物で採集したワタアブラムシ各個 体群の生存曲線と産子数を第 $1 \sim 5$ 図，増殖に関する各 種パラメーターを第 2 表に示した。産子前期間は FC 1 が8.0日で他の 4 個体群と比べて有意に長く, OC - 1 , NC-1，MC-1，MP-1の産子前期間はそれぞれ6.5日， 6.8日，6.2日，7.0日であり，これらの間には有意な差 は見られなかった（Kruskal-Wallis 検定，Dunnの多重 比較検定, $\mathrm{p}>0.05)$ 。 1 頭の雌が次世代に残す雌成虫の

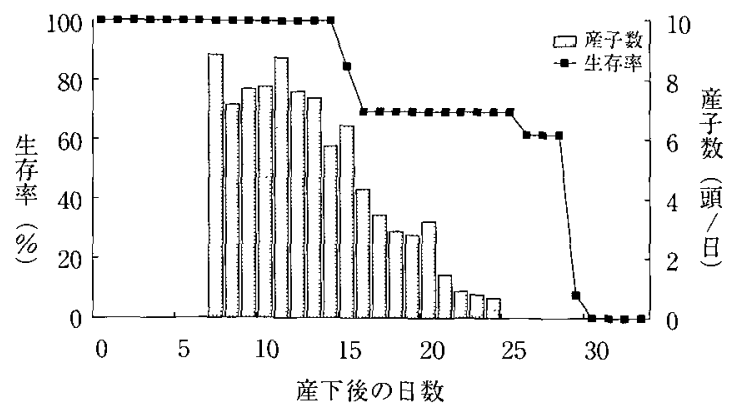

第 1 図福岡県久留米市由来ワタアブラムシ (KC-1)のキュウリに扮ける生存率と 産子数

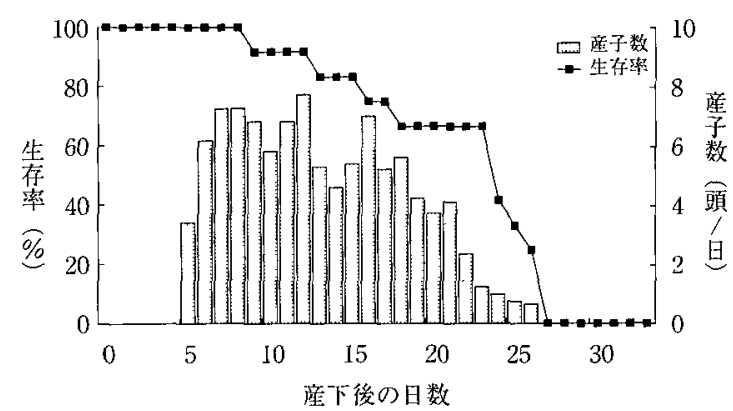

第 2 図大分県宇佐市由来ワタアブラムシ $(O C$ -

1）のキュウリにおける生存率と産子数

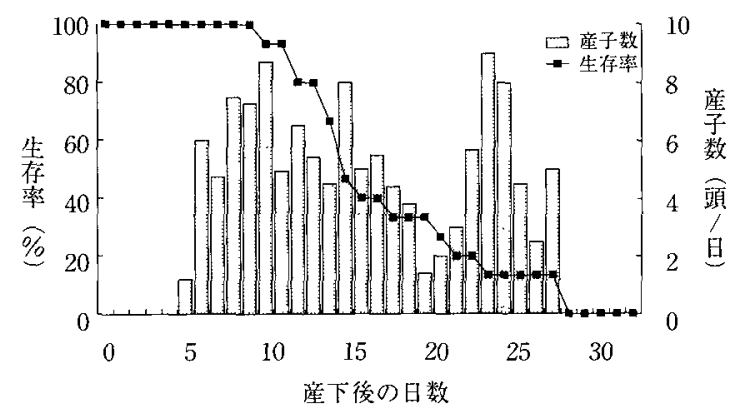

第 3 図長崎県諌早市由来ワタアブラムシ（NC-

1）のキュウリにおける生存率と産子数

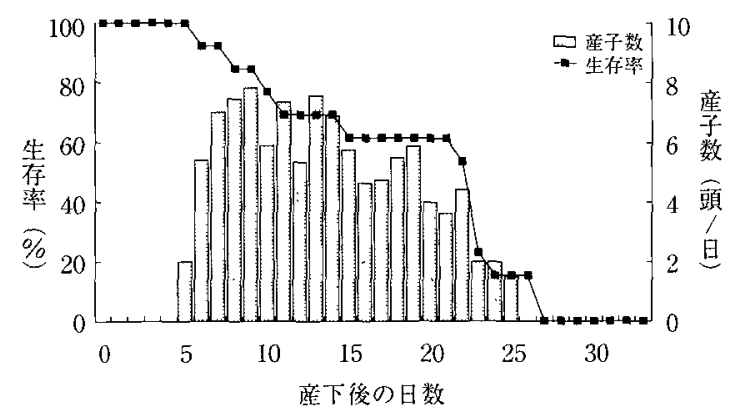

第 4 図 宮崎県佐土原町由来ワタアブラムシ（MC ー1）のキュウリに扔放生存率と産子数

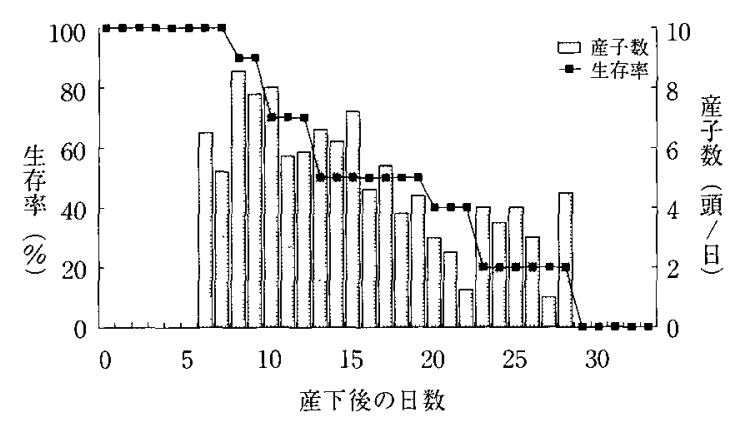

第 5 図 宮崎県川南町由来ワタアブラムシ（MP 1)のキュウリにおけ方生存率と産子数 
第 2 表 ウリ科作物から採集したワタアブラムシのキュウリに打ける增殖能力

\begin{tabular}{|c|c|c|c|c|c|c|}
\hline 個体群 & $\begin{array}{c}\text { 供試数 } \\
\text { (n) }\end{array}$ & $\begin{array}{c}\begin{array}{c}\text { 産子前期間 } \\
\left(\text { 日) } \text { al }^{2}\right.\end{array} \\
\end{array}$ & $\begin{array}{c}\text { 純增殖率 } \\
(\text { Ro })\end{array}$ & $\begin{array}{c}\text { 平均世代時間 } \\
(T)\end{array}$ & $\begin{array}{l}\text { 内的自然 } \\
\text { 增加率 } / \text { 日 }(r)\end{array}$ & $\begin{array}{c}\text { 期間増加率/日 } \\
(\lambda)\end{array}$ \\
\hline $\mathrm{FC}-1$ & 26 & $8.0 \mathrm{a}$ & 80.6 & 9.98 & 0.44 & 1.55 \\
\hline$O C-1$ & 24 & $6.5 b$ & 86.2 & 8.74 & 0.51 & 1.67 \\
\hline $\mathrm{NC}-1$ & 15 & $6.8 \mathrm{~b}$ & 69.2 & 8.83 & 0.48 & 1.62 \\
\hline $\mathrm{MC}-1$ & 26 & $6.2 \mathbf{b}$ & 74.1 & 8.97 & 0.48 & 1.62 \\
\hline $\mathrm{MP}-1$ & 20 & $7.0 \mathrm{~b}$ & 65.9 & 8.91 & 0.47 & 1.60 \\
\hline
\end{tabular}

数を表す純増殖率は OC- 1 が86.2倍, FC-1が80.6倍で あり，MP-1の65.9倍，NC-1の69.2倍と比べて高い傾 向が見られた。しかし，個体群間で世代の長さが異なる ために純增殖率だけでは個体群間の増殖能力を比較する ことはできない。日あたり内的自然增加率は OC-1が 0.51 で最も高く、MP- $1, \mathrm{NC}-1, \mathrm{MC}^{-1}$ - 3 個体群が 0.47〜0.48の值を示した。値が最も低かったものは, FC-100.44であった。平均世代時間は, FC- 1 の9.98日 が最も長く，NC-108.83日が最も短かった。雨者の間 には約 1 日の差が見られたが，他の個体群は両者の中間 の值を示した。日あたり期間增加率 $\left(\lambda=e^{r}\right)$ にも個 体群間で顕著な差は見られなかった。

ワタアブラムシの個体群増殖はカンキツ（Komazaki, 1982），キュウリ（下元， 1983 ; 村井・皘木, 1996)、メ ロン（奈良井・村井、1991），ナズナ（稲泉，1986），才 オイヌフグリ（野里，1987）などで調査されており，笴 主植物により発育や增殖のパラメーターが異なることが 明らかにされている。しかし，ウリ科作物に寄生する個 体群間での増殖能力を比較した報告はない。

九州各地のウリ科作物に寄生するワタアブラムシの個 体群から得ら机た日あたり内的自然增加率は0.44〜0.51 で個体群間で大きな差は見られなかった。これらの值は メロン（奈良井・村井，1991）やキュウリ（下元, 1983 ；村井・積木，1996）で報告されている值と同程度 であった。しかし，カンキッ (Komazaki，1982）やナ ズナ（稲泉，1986）で報告されている值より大きかった。 したがって、これまでの報告と同様にワタアブラムシは ウリ科作物上ではカンキツやナズナに比べて急激な増加 が可能であると考えられる。このことはウリ科作物のワ タアブラムシに対して，寄生蜂などの天敵を利用する際， 他の作物に比べて, 增殖率が高いことを念頭に执いて放 飼量を決定する必要性を示しているものと考えられる。 しかし, 天敵と害虫の個体群変動の䒠態や作物の種類に よる天敵の最適放飼数などを数量的に明らかにするため には，本試験で用いたキュウリ以外のウリ科作物やナス，
ピーマン，イチゴなどについても增殖能力に関与する基 本パラメー夕を明らかにする必要があると考えられる。

\section{摘要}

九州各地から採集したワタアブラムシについて，キュ ウリ（“シャープ1'）の葉片を䬣として $25^{\circ} \mathrm{C}$ 恒温条件で 個体群增殖のパラメーターを求めた。それぞれの個体群

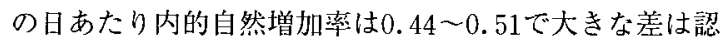
められなかった。九州各地のウリ科作物から採取したワ タアブラムシの增殖能力には大きな変異はないと推測さ れた。

\section{引 用 文 献}

浜弘司・安藤幸夫・細田昭男・鈴木 健・高木 豊 (1995) ワタアブラムシの薬剂抵抗性に関する研究 第 4 報 各クローン系統の各種薬戍に対する感受性. 応動昆 39 (2)：117-125.

細田昭男 - 浜 弘司・鈴木 健 ·安藤幸夫（1993）ワタ アブラムシの薬郕抵抗性に関す研究 第 3 報 ナス とキュウリに笴生する個体群の寄主選好性と有機リン 率抵抗性。応動昆 $37(2): 83-89$.

稲泉三丸（1986）越冬寄主上のワタアブラムシ胎生虫の 生態及び形態。応動昆 $30: 43-49$.

Komazaki. S. (1982) Effect of constant temperatures on population growth of three aphid species. Toxoptera citricidas (Kirkaldy). Aphis citricola Van Der Goot and Aphis gossypii Glover (Homoprera: Aphididea) on citrus. App. Ent. Zool.. 17 (1) : 75-81.

松崎征美（1972）施設栽培に掞什るアブラムシ類の生態 学的梯式 第 1 報增殖椂式. 高知県農技研報. 4：2124.

村井保（1991）アブラムシ類のクローン別飼育法. 島根 農試研報25：78-82.

村井保・皘木久明（1996）モモアカアブラムシとワタア ブラムシの個体群增殖。岡大資生研報 4 ：59-65. 
奈良井祐隆・村井保（1991）ワタアブラムシとマメアブ ラムシの発育と增殖．島根農試研報 $25: 71-78$.

野里和雄（1987）ワタアブラムシの暖地における冬季の 発生消長と增殖に及ほす温度の影響。応動昆 31 ：
162-167.

下元桂（1983）キュウリを加害するワタアブラムシの增 殖パラメーターと生命表. げんせい $43: 83-89$. 